\title{
Checklist of benthic algae from beaches and rocky outcrops on the northeast coast of Pará state, Brazilian Amazonia
}

\author{
Alexandre de Gusmão PEDRINI', Gabriel Irene Pereira GUARINO¹, Felipe dos Santos Pereira DINIZ¹, José \\ Eduardo MARTINELLI FILHO ${ }^{2 *(1)}$ \\ 'Universidade do Estado do Rio de Janeiro, Instituto de Biologia Roberto Alcântara Gomes, Departamento de Biologia Vegetal, Rua São Francisco Xavier, 524 \\ Pavilhão Haroldo Lisboa da Cunha, CEP 20550-013, Rio de Janeiro, RJ, Brazil \\ 2Universidade Federal do Pará, Instituto de Geociências, Laboratório de Oceanografia Biológica, Avenida Augusto Corrêa, 1, CEP 66075-110, Belém, Pará, Brazil \\ *Corresponding author: martinelli@ufpa.br; (D) https://orcid.org/0000-0001-8445-1332
}

\section{ABSTRACT}

We present a checklist with 23 taxa of the benthic phycological flora on three beaches on the northeast coast of Pará state, in the Brazilian Amazon, a rarely surveyed area for algae. Collections were made on substrates like rocky outcrops at Salinópolis municipality, and on trunks, branches and pneumatophores of Laguncularia racemosa and artificial substrates at Marapanim municipality. Despite the limited geographic scale of the sampling, we provide ten new citations for the benthic, marine and estuarine algal taxa of the Pará state coast: six Chlorophyta (Bryopsis pennata, Cladophora coelothrix, C. conferta, Gayralia brasiliensis, Pseudorhizoclonium africanum and Ulva chaetomorphoides), two Rhodophyta (Caloglossa confusa, Centroceras gasparrinii), one Ochrophyta (Bachelotia antillarum) and one Cyanophyta (Coleofasciculus chthonoplastes).

KEYWORDS: Amazon shelf, Neotropical region, phycology, South America, coastal algae

\section{Inventário de algas bentônicas de praias e matacões rochosos da costa nordeste do Pará, Amazônia brasileira}

\section{RESUMO}

Apresentamos um inventário com 23 táxons da flora ficológica bentônica em praias da costa nordeste do estado do Pará, na Amazônia brasileira, uma região raramente amostrada para algas. As coletas foram realizadas em substratos como matacóes no município de Salinópolis, e em troncos, galhos e pneumatóforos de Laguncularia racemosa e substratos artificiais no município de Marapanim. Apesar das limitaçóes da amostragem, nós registramos dez novas citaçóes de algas marinhas e estuarinas bentônicas para a costa do estado do Pará: seis Chlorophyta (Bryopsis pennata, Cladophora coelothrix, C. conferta, Gayralia brasiliensis, Pseudorhizoclonium africanum e Ulva chaetomorphoides), duas Rhodophyta (Caloglossa confusa e Centroceras gasparrinii), uma Ochrophyta (Bachelotia antillarum) e uma Cyanophyta (Coleofasciculus chthonoplastes).

PALAVRAS-CHAVE: Plataforma amazônica, região neotropical, ficologia, América do Sul, algas costeiras

The Amazon coast and shelf is a unique region, leading to the establishment of a singular ecological province, the North Brazil shelf (Spalding et al. 2007). The region includes the coast of Pará state (Brazil), which is dominated by extensive mangroves, vegetated dune-beach ridges and channels, and displays a rich flora, which lacks systematic and detailed studies (Forzza et al. 2010). The polyphyletic algae are one of these taxa of limited knowledge, with only seven published studies for the coast of Amapá and Pará states (Paula et al. 1989;
Fernandes et al. 2005; Fernandes and Alves 2011; Széchy et al. 2012; Moura et al. 2016; Sissini et al. 2017; Vale et al. 2018).

A low diversity of macroalgae is known for the Brazilian Amazon coast, when compared to southern Brazil (Oliveira Filho 1977). The algal diversity is probably underestimated for the region, since recent articles related to macroalgae on the Amazon coast were published (Széchy et al. 2012; Sissini et al. 2017), with highlights to the existence of a benthic flora at mesophotic reefs, composed of 25 Rhodophyta, six Chlorophyta and four Ochrophyta taxa (Moura et al. 2016). 
Additionally, nine taxa from the benthic flora of rhodolith beds were described (Vale et al. 2018). This diversity is probably underestimated since video surveys reported unidentified crustose algae at depths between 70 to $180 \mathrm{~m}$ (Francini-Filho et al. 2018).

The Amazon coast and shelf are under recent anthropogenic impacts (Francini-Filho et al. 2018). The coast is undergoing a process of urbanization and land-use change, while the shelf is affected by predatory trawling since the 1960s (Isaac and Ferrari 2017) and drillings for oil and gas exploration are eminent (ANP 2020). Knowledge of the diversity of benthic algae is thus urgent because the algae are significant primary producers, hosts of associated invertebrates, builders of rhodoliths and source of pharmacological compounds (Simioni et al. 2019).

Here we report a list of benthic algae from three beaches of the coast of Pará, with the first results for algae on rocky outcrops, new occurrences, and range distribution extensions.

Collections occurred on three beaches at the municipalities of Salinópolis (Atalaia beach, on December 7, 2014) and Marapanim (Marudá and Crispim beaches, on March 17 and 18,2017 ) (Figure 1). The coast is influenced by a high tidal amplitude, between $4-6 \mathrm{~m}$, high salinity variation (17 - 40), but homogeneous temperature throughout the year (29 - $\left.31{ }^{\circ} \mathrm{C}\right)$ (e.g. Danin et al. 2020 for Salinópolis). The typical mangrove trees on the northeastern coast of Pará are Avicennia germinans (L.) L. and Laguncularia racemosa (L.) C.F. Gaertn (Bastos et al. 2001).

The Atalaia beach $\left(0^{\circ} 35^{\prime} 35^{\prime \prime} \mathrm{S}, 47^{\circ} 18^{\prime} 50^{\prime \prime} \mathrm{W}\right)$ is impacted by a wave height reaching $1.2 \mathrm{~m}$ (Ranieri and El-Robrini
2016). At the central portion of the beach, natural rocky outcrops were sampled (Figure 2a). Both Marudá (0³7'29”S, $\left.47^{\circ} 37^{\prime} 51^{\prime \prime} \mathrm{W}\right)$ and Crispim (0³5'0”S, 4739'14”W) beaches are surrounded by mangroves, where the algae were collected (Figure 2b). Abandoned and eroded civil constructions were also sampled at Crispim beach (Figure 2c). Small mangrove patches are distributed at Marudá and Crispim beaches, between tidal channels and sand dunes.

Sampling was performed during the low tide, at the midlittoral sector of the beaches. The algae were removed

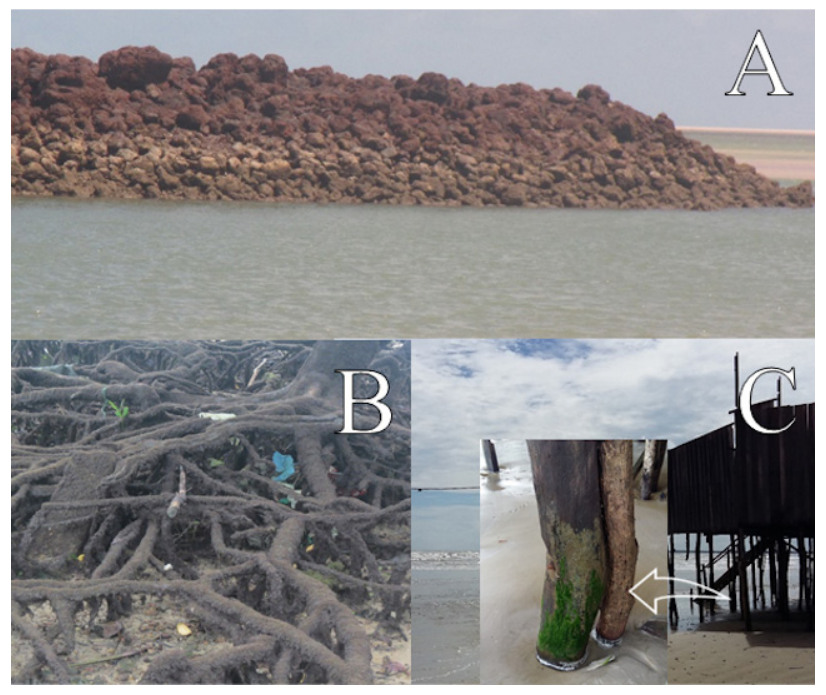

Figure 2. Examples of sampled substrates. A - Rocky outcrop (maximum height about $1 \mathrm{~m}$ ) at Atalaia beach during the low tide; B - Roots and branches of Laguncularia racemosa at Marudá beach; C-Crispim beach, with civil constructions as substrata for Pseudorhizoclonium africanum.

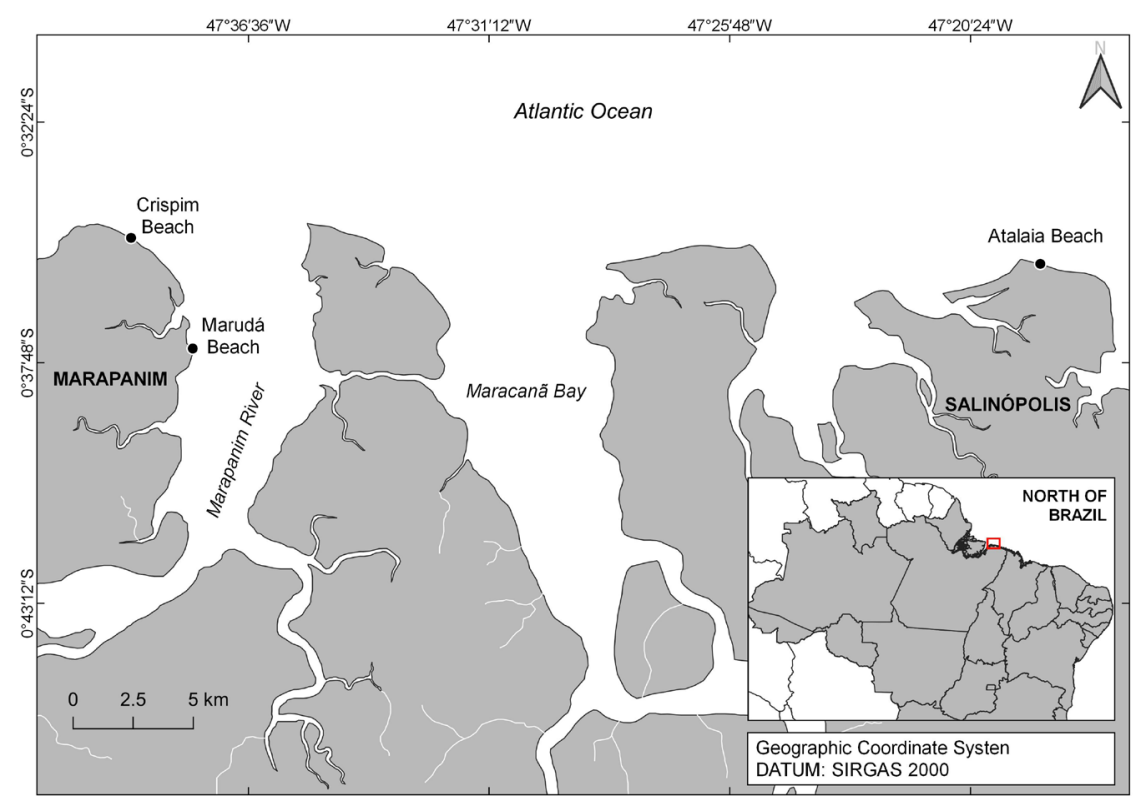

Figure 1. Location of the study area on the northern Brazilian coast, and location of the sampled beaches of Atalaia (Salinópolis municipality), Marudá and Crispim (Marapanim municipality) on the northeastern coast of Pará state. 
using stainless steel spatulas and transferred to clean containers with buffered formaldehyde diluted in seawater at a final concentration of $4 \%$. Samples were kept in the dark until analysis.

The systematic classification from Wynne's (2017) checklist was adopted, and the names of the taxa were updated by checking the AlgaeBase database (Guiry and Guiry 2020). Microscopic analyses were made using an optical microscope and a stereomicroscope. Length and width of stems, blades and other structures were measured with an imaging system coupled to the stereomicroscope. Identified voucher specimens were deposited in the herbaria of Universidade do Estado do Rio de Janeiro (HRJ), Universidade de Sáo Paulo (SPF) and Universidade Estadual de Feira de Santana (HUEFS).

The phycological flora was represented by 23 taxa: 12 Rhodophyta (52.2\%), nine Chlorophyta (39.1\%), one Ochrophyta (4.3\%) and one Cyanophyta (4.3\%). Most of the taxa $(91.3 \%)$ were restricted to a single beach, with only two exceptions: Bostrychia radicans and Pseudorhizoclonium africanum (Table 1). Atalaia had the highest richness with 17 taxa (10 Rhodophyta, six Chlorophyta and one Ochrophyta) and a total of $69.6 \%$ exclusive taxa. Six taxa were recorded at Marudá: two Rhodophyta, three Chlorophyta and the Cyanophyta Coleofasciculus chthonoplastes. Four taxa (17.4\%) were exclusive at Marudá. At Crispim, only four taxa were detected: two Rhodophyta and two Chlorophyta, two (8.7\%) being exclusive.

The most representative families from each division were: Cladophoracaeae (Chlorophyta) with five taxa (21.7\%), Rhodomelaceae (Rhodophyta) with three taxa (13\%) and Bachelotiaceae (Ochrophyta) with a single taxon (4.3\%) (Table 1). The Rhodophyta Bostrychia radicans was the most frequent alga and the only one occurring at all beaches, while Pseudorhizoclonium africanum was the only one to occur at both Marapanim beaches. The Ochrophyta were present only at Atalaia, represented by Bachelotia antillarum, while small patches of Ulva linza were restricted to wood pilings from houses built at Crispim and Ulva chaetomorphoides was restricted to Marudá. Four epiphytic taxa (17.4\%) were found on the sampled macroalgae: Coleofasciculus chtonoplastes, Acrochaetium sp., and Erythrotrichia carnea were observed on Bostrychia radicans, while Stylonema alsidii was found in association with Bostrychia moritziana and Hypnea pseudomusciformis.

With 23 taxa reported in this study, there are now 77 taxa of benthic, marine and estuarine algae registered for the northern coast of Brazil (all for Pará and Amapá states), 45 being Rhodophyta, 8 Ocrophyta, 22 Chlorophyta and 2 Cyanophyta. The older publications on the coasts of Pará and Amapá pointed to a low diversity of algae because the area is dominated by mangroves and river mouths (Oliveira Filho
1977; Paula et al. 1989), but probably also due to limited sampling.

One of the most complete studies on the distribution of coastal algae for the Brazilian Amazon described 11 taxa for the mangroves of the municipality of Bragança (Fernandes et al. 2005), and nearly half of those were also reported here. At the same mangroves, an additional five species of Rhodophyta were recorded, all attached to the pneumatophores of Avicennia germinans (Fernandes and Alves 2011). We assume that rocky outcrops were not sampled in earlier studies, as they were not previously mentioned.

The recent increase in richness of benthic macroalgae for the Brazilian Amazon coast is due to sampling of the previously poorly explored rocky outcrops, where taxa such as Hypnea pseudomusciformis, Pterocladiella sp., Bachelotia antillarum, Bryopsis pennata, Cladophora coelothrix and C. conferta were detected. The algal diversity in these outcrops is potentially limited by the low salinity of surrounding coastal waters during the rainy season (Lara and Cohen 2006). Another factor contributing to the richness increase is the record of many taxa at the recently mapped Amazon reefs. Genera like Dictyota and Lobophora were found growing over coral reefs at depths down to $120 \mathrm{~m}$ (Moura et al. 2016). In addition, a list of nine crustose algae were described as components of the rhodolith beds in the heterogenous Amazon reef (Vale et al. 2018). These discoveries lead us to speculate that the number of algal taxa for the Amazon coast and shelf is underestimated.

Despite the spatial and temporal constrain, our collections resulted in the highest number of coastal and estuarine algal taxa ever reported for the coast of Pará state. This suggests that a standardized, periodical sampling effort for benthic algae along the Amazon coast will possibly result in a much richer dataset and the description of new taxa. Furthermore, the lack of molecular studies, with the exception of the pelagic Sargassum (Sissini et al. 2017) and the genus Bostrychia (Fontes 2012), hinders the identification of a potentially hidden diversity in the phycological community.

The higher richness observed at Atalaia was probably owed to it being the only beach where rocky outcrops were sampled. However, seasonality may also have influenced richness, as sampling at Atalaia occurred by the end of the dry season, when the Amazon plume is retracted, and oceanic intrusion reaches the coast (Molleri et al. 2010). Saline waters during the previous months would probably allow the colonization by marine taxa like Bachelotia antillarum, Centroceras gasparrinii and Gayralia brasiliensis. Marapanim was sampled during the middle of the rainy season, when the river plume is extended and salinity values may be as low as zero, with an average of $13 \pm 6$ (Silva and Martinelli-Lemos 2012). These hypotheses should be tested with an appropriate sampling design, as seasonal variability in algae was rarely reported in the region (Fernandes and Alves 2011). 
Table 1. Algae collected at the three sampled beaches of the coast of Pará state, Brazilian Amazonia. A : Atalaia; C: Crispim; M: Marudá; HR: herbarium registry; HRJ: herbarium from Universidade do Estado do Rio de Janeiro; SPF: herbarium from Universidade de São Paulo; HUEFS: herbarium from Universidade Estadual de Feira de Santana. A + sign indicates the presence of the algae on the beach.

\begin{tabular}{|c|c|c|c|c|c|}
\hline Superior taxa & Species & A & C & M & $\mathrm{HR}$ \\
\hline \multicolumn{6}{|l|}{ Rhodophyta } \\
\hline \multicolumn{6}{|l|}{ Acrochaetiales } \\
\hline Acrochaetiaceae & Acrochaetium sp. & + & - & - & HRJ 12785 \\
\hline \multicolumn{6}{|l|}{ Ceramiales } \\
\hline \multirow[t]{3}{*}{ Rhodomelaceae } & Bostrychia moritziana (Sonder ex Kützing) J. Agardh & + & - & - & HRJ 12786 \\
\hline & Bostrychia radicans (Montagne) Montagne in Orb. & + & + & + & HRJ 12785, 12870, 12874, 12882 \\
\hline & Polysiphonia scopulorum Harvey & + & - & - & HRJ 12792 \\
\hline \multirow[t]{2}{*}{ Delesseriaceae } & Caloglossa leprieurii (Montagne) G. Martens & + & - & - & HRJ 12788 \\
\hline & Caloglossa confusa Krayesky, J.A. West \& M. Kamiya & - & + & - & HRJ 12871 \\
\hline Ceramiaceae & Centroceras gasparrinii (Meneghini) Kützing & + & - & - & HRJ 12789 \\
\hline Erythrotrichiaceae & Erythrotrichia carnea (Dillwyn) J. Agardh & - & - & + & HRJ 1212874 \\
\hline \multicolumn{6}{|l|}{ Gelidiales } \\
\hline Gelidiaceae & Gelidium pusillum (Stackhouse) Le Jolis & + & - & - & SPF 57940 \\
\hline Pterocladiaceae & Pterocladiella sp. & + & - & - & SPF 57938 \\
\hline \multicolumn{6}{|l|}{ Gigartinales } \\
\hline Cystocloniaceae & Hypnea pseudomusciformis Nauer, Cassano \& Oliveira & + & - & - & HRJ 12794, 12793; SPF 57938 \\
\hline \multicolumn{6}{|l|}{ Stylonematales } \\
\hline Stylonemataceae & Stylonema alsidii (Zanardini) K. M. Drew & + & - & - & HRJ 12786,12793 \\
\hline \multicolumn{6}{|l|}{ Ochrophyta } \\
\hline \multicolumn{6}{|l|}{ Ectocarpales } \\
\hline Bachelotiaceae & Bachelotia antillarum (Grunow) Gerloff & + & - & - & HRJ 12784 \\
\hline \multicolumn{6}{|l|}{ Chlorophyta } \\
\hline \multicolumn{6}{|l|}{ Bryopsidales } \\
\hline Bryopsidaceae & Bryopsis pennata J.V.Lamouroux & + & - & - & HRJ 12787 \\
\hline \multicolumn{6}{|l|}{ Cladophorales } \\
\hline \multirow[t]{4}{*}{ Cladophoraceae } & Cladophora brasiliana G.Martens & + & - & - & HRJ 12790,12791 \\
\hline & Cladophora coelothrix Kützing & + & - & - & HRJ 12792 \\
\hline & Cladophora conferta P. Crouan \& H. Crouan in Schramm \& Mazé & + & - & - & HUEFS 219018 \\
\hline & Pseudorhizoclonium africanum (Kützing) Boedeker & - & + & + & HRJ 12868, 12881, 2879, 12878 \\
\hline \multicolumn{6}{|l|}{ Siphonocladales } \\
\hline Boodleaceae & Cladophoropsis membranacea (Hofman Bang ex C. Agardh) Børgesen & - & - & + & HRJ $12872,12875,2876,12877,12867$ \\
\hline \multicolumn{6}{|l|}{ Ulvales } \\
\hline Gayraliaceae & Gayralia brasiliensis Pellizzari, M.C.Oliveira \& N.S.Yokoya & + & - & - & HRJ 12866, 12869 \\
\hline \multirow[t]{2}{*}{ Ulvaceae } & Ulva linza L. & - & + & - & HRJ 12883 \\
\hline & Ulva chaetomorphoides (Børgesen) Hayden et al. & - & - & + & HRJ 12865,12873 \\
\hline \multicolumn{6}{|l|}{ Cyanophyta } \\
\hline \multicolumn{6}{|l|}{ Oscillatoriales } \\
\hline Coleofasciculaceae & $\begin{array}{c}\text { Coleofasciculus chthonoplastes (Thuret ex Gomont) M.Siegesmund, } \\
\text { J.R.Johansen \& T.Friedl }\end{array}$ & - & - & + & HRJ 12882 \\
\hline
\end{tabular}

Our survey resulted in new occurrences and distribution extension for nearly half of the recorded taxa $(43.5 \%)$. We provide a new record for a Chlorophyta for Pará state only (Pseudorhizoclonium africanum), and nine new occurrences for the entire northern coast of Brazil: Bryopsis pennata, Cladophora coelothrix, C. conferta, Gayralia brasiliensis, Ulva chaetomorphoides, Caloglossa confusa, Centroceras gasparrinii, Bachelotia antillarum and Coleofasciculus chthonoplastes.
The new occurrences reported in here resulted in an increase in the benthic, marine and estuarine algal taxa registered for the Pará state coast. Our results suggest that the benthic marine flora diversity of the Brazilian Amazon coast is underestimated, and sampling efforts should be increased to properly assess the diversity and enable the sustainable management of these taxa. 


\section{ACKNOWLEDGMENTS}

We acknowledge Dr. Sebastião J. S. Neto, for the deposit of voucher specimens at the HRJ herbarium, Dra. Aigara Alves for the revision of Cladophora; Dra. Mariana Oliveira and Dra. Cintia Iha, for the identification of Pterocladiella, our colleagues Thiago Franklin and Pedro Marques, for some of the identifications, Arnaldo F. Queiroz for the map design, and Dr. M. Wynne for scientific revision and English amendments.

\section{REFERENCES}

ANP. 2020. Agência Nacional do Petróleo, Gás Natural e Biocombustível. (http://www.anp.gov.br). Accessed on 30 Apr 2020.

Bastos, M. De N.C.; Santos, J.U.M.; Amaral, D.D.; Costa Neto, S.V. 2001. Alterações ambientais na vegetação litorânea do Nordeste do Pará. In: Prost, M.T.R. da C.; Mendes, A.C. (Ed.). Ecossistemas Costeiros: Impactos e Gestão Ambiental. v.1. Museu Paraense Emilio Goeldi, Belém, p.29-38.

Danin, A.P.F.; Pombo, M.; Martinelli-Lemos, J.M.; Santos, C.R.M. Dos; Petracco, M. 2020. Population ecology of the hermit crab Clibanarius symmetricus (Anomura: Diogenidae) on an exposed beach of the Brazilian Amazon coast. Regional Studies in Marine Science, 33: 100944.

Fernandes, M.E.B.; Alves, E.F.S. 2011. Occurrence and distribution of macroalgae (Rhodophyta) associated with mangroves on the Ajuruteua peninsula, Bragança, Pará, Brazil. Uakari, 7: 35-42.

Fernandes, M.E.B.; Silva, E.F.; Lima, J.F.; Varela, E.S.; Hercos, A.P.; Fernandes, C.M.; et al. 2005. Distribuição espacial das macroalgas associadas às florestas de mangue na península de Ajuruteua, Bragança-Pará. Boletim do Laboratório de Hidrobiologia, 18: 11-18.

Fontes, K.A. de A. 2012. Taxonomia e distribuiçáo geográfica do gênero Bostrychia Montagne (Ceramiales-Rhodophyta) nos manguezais do litoral brasileiro. Doctoral thesis, Universidade Federal Rural de Pernambuco, Brazil. 94p. (http://www.tede2. ufrpe.br:8080/tede2/handle/tede2/4843)

Forzza, R.C.; Baumgratz, J.F.A.; Bicudo, C.E.M.; Carvalho Jr., A.A.; Costa, A.; Costa, D.P.; et al. 2010. Catálogo de Plantas e Fungos do Brasil [online]. v.1. Andrea Jakobsson Estúdio: Instituto de Pesquisas do Jardim Botânico do Rio de Janeiro, Rio de Janeiro, 871p.

Francini-Filho, R.B.; Asp, N.E.; Siegle, E.; Hocevar, J.; Lowyck, K.; D'avila, N.; et al. 2018. Perspectives on the Great Amazon Reef: Extension, Biodiversity, and Threats. Frontiers in Marine Science 5: 142. doi: 10.3389/fmars.2018.00142.

Guiry, M.D.; Guiry, G.M. 2020. AlgaeBase. Worldwide electronic publication, National University of Ireland, Galway. (https:// www.algaebase.org). Accessed on 22 Jun 2020.

Isaac, V.J.; Ferrari, S.F. 2017. Assessment and management of the north Brazil shelf large marine ecosystem. Environmental Development, 22: 97-110.
Lara, R.J.; Cohen, M.C.L. 2006. Sediment porewater salinity, inundation frequency and mangrove vegetation height in Bragança, North Brazil: an ecohydrology-based emprical model. Wetlands Ecology and Management, 14: 3490358.

Molleri, G.S.F.; Novo, E.M.L.M.; Kampel, M. 2010. Space-time variability of the Amazon River plume based on satellite ocean color. Continental Shelf Research, 30: 342-352.

Moura, R.L.; Amado-Filho, G.M.; Moraes, F.C.; Brasileiro, P.S.; Salomon, P.S.; Mahiques, M.M.; et al. 2016. An extensive reef system at the Amazon River mouth. Science Advances 2: e1501252.

Oliveira-Filho, E.C. 1977. Algas Marinhas Bentônicas do Brasil. Free-docency thesis, Universidade de São Paulo, Brazil. 407p. (https://teses.usp.br/teses/disponiveis/livredocencia/41/tde14032013-171424/publico//LivreDocencia_Eurico.pdf)

Paula, E.J. de; Ugadim, Y.; Kanagawa, A.I. 1989. Macroalgas de manguezais da Ilha de Maraca, Estado do Amapá, Brasil. Insula, 19 supl: 95-114.

Ranieri, L.A.; El-Robrini, M. 2016. Condição oceanográfica, uso e ocupação da costa de Salinópolis (Setor Corvina - Atalaia), nordeste do Pará, Brasil. Revista de Gestão Costeira Integrada, 16: 133-146.

Silva, D.C.; Martinelli-Lemos, J.M. 2012. Species composition and abundance of the benthic community of Axiidea and Gebiidea (Crustacea: Decapoda) in the Marapanim Bay, Amazon estuary, Northern Brazil. Zoologia, 29: 144-158.

Simioni, C.; Hayashi, L.; Oliveira, M.C. 2019. Seaweed resources of Brazil: what has changed in 20 years? Botanica Marina, 62: 1-10.

Sissini, M.N.; Barros-Barreto, M.B.B. De.; Széchy, M.T.M.; Lucena, M.B. De.; Oliveira, M.C.; Gower, J.; et al. 2017. The floating Sargassum (Phaeophyceae) of the South Atlantic Ocean - likely scenarios. Phycologia, 56: 321-328.

Spalding, M.D.; Fox, H.E.; Allen, G.R.; Davidson, N.; Finlayson, M.; Halpern, B.S.; et al. 2007. Marine ecoregions of the world: a bioregionalization of coastal and shelf areas. BioScience, 57: 573-583.

Széchy, M.T.M.; Guedes, P.M.; Baeta-Neves, M.H.; Oliveira, E.N. 2012. Verification of Sargassum natans (Linnaeus) Gaillon (Heterokontophyta: Phaeophyceae) from the Sargasso Sea off the coast of Brazil, western Atlantic Ocean. Check List, 8: 638-641.

Vale, N.F.; Amado-Filho, G.M.; Braga, J.C.; Brasileiro, P.S.; Karez, C.S.; Moraes, F.C.; et al. 2018. Structure and composition of rhodoliths from the Amazon River mouth, Brazil. Journal of South American Earth Science, 84: 149-159.

Wynne, M.J. 2017. A checklist of benthic marine algae of the tropical and subtropical western Atlantic: fourth revision. Nova Hedwigia, 145: 1-202.

RECEIVED: 24/10/2020

ACCEPTED: $17 / 02 / 2021$

ASSOCIATE EDITOR: Natalia Ivanauskas 